\title{
Chlorine Dioxide-Iodide-Methyl Acetoacetate Oscillation Reaction Investigated by UV-Vis and Online FTIR Spectrophotometric Method
}

\author{
Laishun Shi, Xiaomei Wang, Na Li, Jie Liu, and Chunying Yan \\ School of Chemistry and Chemical Engineering, Shandong University, South Campus, Jinan 250061, China \\ Correspondence should be addressed to Laishun Shi, shils888@yahoo.com.cn
}

Received 16 October 2011; Accepted 8 December 2011

Academic Editors: Y. Tang and S. Wang

Copyright (C) 2012 Laishun Shi et al. This is an open access article distributed under the Creative Commons Attribution License, which permits unrestricted use, distribution, and reproduction in any medium, provided the original work is properly cited.

\begin{abstract}
In order to study the chemical oscillatory behavior and mechanism of a new chlorine dioxide-iodide ion-methyl acetoacetate reaction system, a series of experiments were done by using UV-Vis and online FTIR spectrophotometric method. The initial concentrations of methyl acetoacetate, chlorine dioxide, potassium iodide, and sulfuric acid and the $\mathrm{pH}$ value have great influence on the oscillation observed at wavelength of $289 \mathrm{~nm}$. There is a preoscillatory or induction period, and the amplitude and the number of oscillations are associated with the initial concentration of reactants. The equations for the triiodide ion reaction rate changing with reaction time and the initial concentrations in the oscillation stage were obtained. Oscillation reaction can be accelerated by increasing temperature. The apparent activation energies in terms of the induction period and the oscillation period were $26.02 \mathrm{KJ} / \mathrm{mol}$ and $17.65 \mathrm{KJ} / \mathrm{mol}$, respectively. The intermediates were detected by the online FTIR analysis. Based upon the experimental data in this work and in the literature, a plausible reaction mechanism was proposed for the oscillation reaction.
\end{abstract}

\section{Introduction}

Chemical oscillations are systems of chemicals that exhibit time-based fluctuations when they are far from equilibrium. The most studied chemical oscillation is the BelousovZhabotinsky (BZ) reaction, which is one of a class of reactions that serve as a classical example of nonequilibrium thermodynamics, resulting in the establishment of a nonlinear chemical oscillator. The detailed mechanism was first described by Field et al. (FKN) [1]. Field and Noyes constructed a simplified mathematical model, now known as the Oregonator [2]. Chlorite- and chlorine-dioxide-based chemical oscillations play an important role in "nonlinear chemistry." Chlorite-iodide reaction has become, next to the Belousov-Zhabotinsky (BZ) reaction, perhaps the most widely studied reaction in nonlinear chemical dynamics. These studies have been concerned with the system nonlinear features, such as oscillations, bistability, stirring and premixing effects, spatial phenomena [3], and detailed mechanistic investigations.

Chlorine dioxide and sodium chlorite have close connection in the reaction. They can transfer each other in the whole $\mathrm{pH}$ ranges. The oxidation of iodide by chlorine dioxide was reported by Bray where it was used in the analytical determination of chlorine dioxide [4]. The kinetic study of the reaction between chlorine dioxide and potassium iodide in aqueous solution was investigated by Fukutomi and Gordon where two distinctly different rates were observed in the $\mathrm{pH}$ range 5.5-8.5 [5]. The first reaction corresponds to the rapid formation of the intermediate $\left[\mathrm{ClO}_{2} \mathrm{I}^{-}\right]$. The second corresponds to the decomposition of the intermediate, which results in the formation of $\mathrm{ClO}_{2}{ }^{-}$and $\mathrm{I}_{2}$. The reaction between iodide ion and chlorite ion exhibits a remarkable variety of kinetic phenomena [6]. Responses to single and periodic pulse perturbations have been studied experimentally and numerically by Dolnik and Epstien for the reaction of chlorine dioxide and iodide ion in a stirred tank reactor [7]. Excitability with transient oscillations was obtained for perturbations by chlorine dioxide or chlorite, while stimulation by iodide produced no excitable response.

The dynamical behavior of the chlorine dioxide-iodide reaction has been studied in a system consisting of two continuous flow stirred tank reactors (CSTRs) [8]. By introducing an additional reactant to chlorite-iodide system 
that can react to regenerate the iodide consumed during each cycle of oscillation, De Kepper et al. constructed the chlorite-iodate-thiosulfate and the chlorite-iodide-malonic acid (MA) systems, which oscillate in a closed (batch) as well as in an open system $[3,9,10]$. The batch oscillation in the reaction of chlorine dioxide with iodine and malonic acid was studied by Lengyel et al. [11-13]. The modeling of the Turing structures in the chlorite-iodide-malonic acid-starch reaction system was also further investigated $[14,15]$.

Illumination of the chlorine dioxide-iodine-malonic acid reaction with visible light suppresses oscillations and shifts the steady state of the reaction to lower concentrations of iodide ions [16]. In the system with starch, illumination results in a strong decrease of the steady-state concentration of the triiodide-starch complex. They suggested a simple mechanism, in which iodine atoms produced by photodissociation of molecular iodine initiate reduction of chlorine dioxide to chlorite and oxidation of iodide ions to iodine. The oxidation of iodide ion by chlorine dioxide has been studied by stopped-flow techniques at $I=1.0 \mathrm{~mol} / \mathrm{L}$ $\left(\mathrm{NaClO}_{4}\right)$ [17]. A two-term rate law was confirmed for the reaction. Strier et al. and Szalai and De Kepper investigated the Turing patterns, spatial bistability, and front interactions in the $\left[\mathrm{ClO}_{2}, \mathrm{I}_{2}, \mathrm{I}^{-}, \mathrm{CH}_{2}(\mathrm{COOH})_{2}\right]$ reaction $[18,19]$. The development of spiral pattern in a model representing chlorite-iodide-malonic acid reaction was investigated theoretically and numerically by Riaz and Ray [20]. A set of serially coupled flow reactors was modeled by Long et al. which contained chlorite-iodide oscillators [21]. By independently varying the reactor flow rates it is possible to produce oscillatory systems with differing periods where the ratio of the period of oscillation between reactors is always an integer value.

In previous papers we have studied the chlorine dioxideiodine-malonic acid-sulfuric acid oscillation reaction [22] and sodium chlorite-iodine-ethyl acetoacetate oscillation reaction [23]. As is known, methyl acetoacetate (MAA) and malonic acid (MA) have similar properties in that both molecules contain an active $\mathrm{CH}_{2}$ group. By using methyl acetoacetate instead of malonic acid, oscillation should also occur for the system of $\mathrm{ClO}_{2}$-KI-MAA. In order to study the chlorine dioxide-iodide-methyl acetoacetate oscillator reaction better, it is necessary to investigate all of the factors that influence the reaction. Taking into account these factors, we found that oscillations can occur at $289 \mathrm{~nm}$ for the triiodide ion. Equations for the triiodide ion reaction rate changing with reaction time and the initial concentrations in the oscillation stage were obtained. The intermediates were detected by online FTIR analysis. A plausible reaction mechanism was proposed for the oscillation reaction.

\section{Materials and Methods}

2.1. Materials. Chlorine dioxide aqueous solutions were prepared from sodium chlorite and dilute sulfuric acid and were purified by bubbling of the resulting $\mathrm{ClO}_{2}$ through a $10 \%$ sodium chlorite aqueous solution to remove trace $\mathrm{Cl}_{2}$, then absorbing it in distilled water. Stock solutions of $\mathrm{ClO}_{2}$ were stored in darkness at $5^{\circ} \mathrm{C}$. The $\mathrm{ClO}_{2}$ concentration was determined by the iodometric titration method. Potassium iodide solution was prepared by dissolving a certain amount of potassium iodide solid (AR) in a $500 \mathrm{~mL}$ measuring flask filled with distilled water. A methyl acetoacetate (MAA) aqueous solution was prepared by dissolving $3.00 \mathrm{~mL}$ methyl acetoacetate in a $500 \mathrm{~mL}$ measuring flask filled with distilled water. Citric acid-disodium hydrogen phosphate buffer solutions with different $\mathrm{pHs}$ were prepared from $0.2 \mathrm{~mol} / \mathrm{L}$ $\mathrm{Na}_{2} \mathrm{HPO}_{4}$ solution and $0.1 \mathrm{~mol} / \mathrm{L}$ citric acid solution. The sulfuric acid concentration was $0.04825 \mathrm{~mol} / \mathrm{L}$. All other chemicals were of the highest purity commercially available and were used as received.

2.2. Methods. The reaction was started by injecting a small volume of one of the reactants into a mixture containing the other components inside a spectrophotometric cell. The mixing time is about 2 or $3 \mathrm{~s}$. Spectrophotometric measurements were performed in a TU-1800PC UVVis spectrophotometer (Beijing Puxi Tongyong Instrument Company, Beijing, China). A complete spectrum of the reaction mixture could be obtained at each second of reaction time. All measurements were performed at room temperature.

For the experiment of the temperature influence on the oscillation, a super electric-heated thermostatic water bath was used. The temperature of the water bath was set to $25^{\circ} \mathrm{C}, 30^{\circ} \mathrm{C}, 40^{\circ} \mathrm{C}, 45^{\circ} \mathrm{C}$, and $50^{\circ} \mathrm{C}$, respectively. The reactants were heated in the water bath. Following the above operation procedure, a group of oscillation curves about the absorbance of $\mathrm{I}_{3}{ }^{-}$changing with reaction time at different temperatures could be obtained.

2.3. Online FTIR Analysis during the Oscillation Reaction. The online FTIR analysis was performed on a ReactIR 4000 spectrophotometer (Mettler-Toledo AutoChem, Inc., USA). FTIR spectra were recorded over the 648 to $4000 \mathrm{~cm}^{-1}$ wavenumber range at a resolution of $8 \mathrm{~cm}^{-1}$. The reaction conditions were fixed at $[\mathrm{MAA}]_{0}=6.29 \times 10^{-3} \mathrm{~mol} / \mathrm{L}$, $\left[\mathrm{H}_{2} \mathrm{SO}_{4}\right]_{0}=4.91 \times 10^{-3} \mathrm{~mol} / \mathrm{L},\left[\mathrm{ClO}_{2}\right]_{0}=7.60 \times$ $10^{-4} \mathrm{~mol} / \mathrm{L}$, and $[\mathrm{KI}]_{0}=3.62 \times 10^{-4} \mathrm{~mol} / \mathrm{L}$.

\section{Results and Discussion}

3.1. Wavelength Selection. Figure 1 gives the UV-Vis spectrum of $\mathrm{ClO}_{2}-\mathrm{KI}-\mathrm{MAA}-\mathrm{H}_{2} \mathrm{SO}_{4}$ reaction system at equilibrium. There are two absorption peaks at $289 \mathrm{~nm}$ and $350 \mathrm{~nm}$, which should be the characteristic peaks of triiodide ion [24]. Therefore, the wavelength of $289 \mathrm{~nm}$ is selected in the following investigation.

3.2. Potassium Iodide Initial Concentration. We carried out the reaction of $\mathrm{ClO}_{2}$-KI-MAA in $\mathrm{H}_{2} \mathrm{SO}_{4}$ medium by measuring the absorbance change with reaction time at $289 \mathrm{~nm}$. The reaction conditions were fixed at $[\mathrm{MAA}]_{0}=6.29 \times$ $10^{-3} \mathrm{~mol} / \mathrm{L},\left[\mathrm{ClO}_{2}\right]_{0}=8.77 \times 10^{-4} \mathrm{~mol} / \mathrm{L}$, and $\left[\mathrm{H}_{2} \mathrm{SO}_{4}\right]_{0}=$ $3.50 \times 10^{-3} \mathrm{~mol} / \mathrm{L}$ by changing the initial concentration of potassium iodide. Figure 2 gives the absorbance changes with 


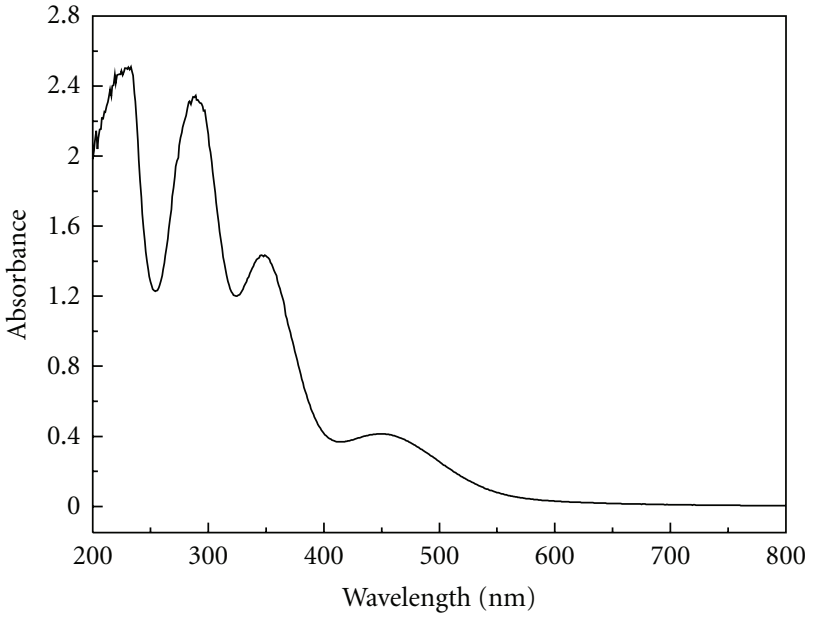

FIgURE 1: The UV-Vis spectrum of the reaction system.

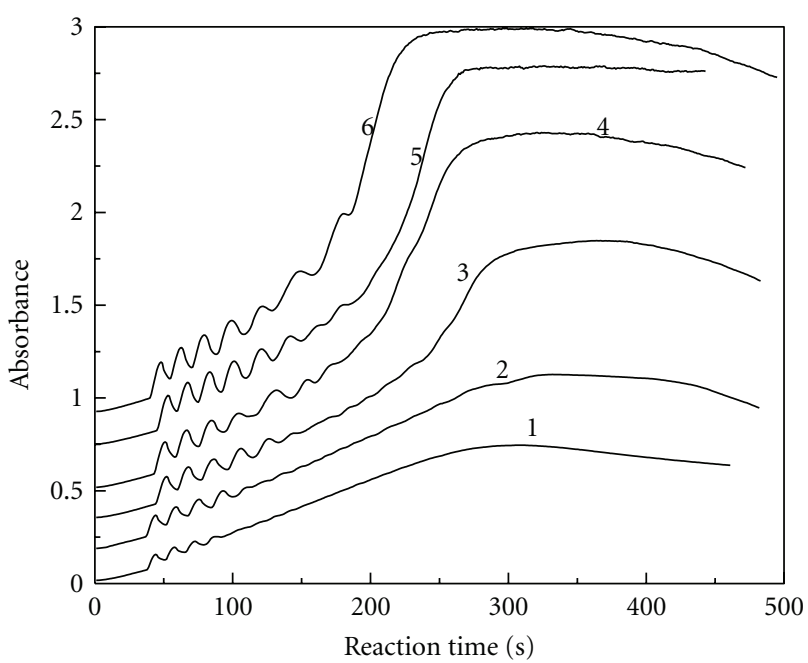

FIGURE 2: The absorbance versus reaction time at $289 \mathrm{~nm}$ for the triiodide ion. $\left[\mathrm{ClO}_{2}\right]_{0}=8.77 \times 10^{-4} \mathrm{~mol} / \mathrm{L},[\mathrm{MAA}]_{0}=6.29 \times$ $10^{-3} \mathrm{~mol} / \mathrm{L},\left[\mathrm{H}_{2} \mathrm{SO}_{4}\right]_{0}=3.50 \times 10^{-3} \mathrm{~mol} / \mathrm{L},[\mathrm{KI}]_{0}=2.72 \times$ $10^{-3} \mathrm{~mol} / \mathrm{L}$ (curve 1 ), $3.23 \times 10^{-3} \mathrm{~mol} / \mathrm{L}$ (curve 2 ), $3.40 \times 10^{-3} \mathrm{~mol} / \mathrm{L}$ (curve 3), $3.57 \times 10^{-3} \mathrm{~mol} / \mathrm{L}$ (curve 4 ), $3.74 \times 10^{-3} \mathrm{~mol} / \mathrm{L}$ (curve 5), $4.08 \times 10^{-3} \mathrm{~mol} / \mathrm{L}$ (curve 6 ).

reaction time at $289 \mathrm{~nm}$ for the triiodide ion. Successive curves are shifted up by an absorbance unit for better viewing, since without a shift the curves overlap. A similar treatment was also done in Figures 3 to 8 . The oscillation phenomenon does not occur as long as the reactants are mixed. There is a preoscillatory or induction period. The oscillation phenomenon is obvious in the range of $[\mathrm{KI}]_{0}=$ $2.72 \times 10^{-4} \mathrm{~mol} / \mathrm{L}-4.08 \times 10^{-4} \mathrm{~mol} / \mathrm{L}$. The amplitude and the number of oscillations are associated with the initial concentration of potassium iodide, the amplitude increases with the initial concentration of potassium iodide, and also the number of oscillations increases.

We can differentiate the curves in Figure 2, and get the new curves of triiodide ion reaction rate $(\nu)$ change with reaction time. The new curves were processed by nonlinear curve fitting. We got the following equation (1) of triiodide ion reaction rate changing with reaction time and the initial concentration of potassium iodide in the oscillation stage:

$$
v=\frac{\mathrm{d}\left[\mathrm{I}_{3}{ }^{-}\right]}{\mathrm{d} t}=P \operatorname{Sin}\left[\frac{2 \pi(t-18)}{\mathrm{T}}\right],
$$

where $P$ represents the amplitude of the sine function. That is to say, it represents the amplitude of the oscillation reaction. The value of $P$ is dependent on the initial concentration of potassium iodide. We observe that $P$ follows the following equation:

$$
P=-1.33 \times 10^{-2}+8.83[\mathrm{KI}]_{0}
$$

with the linear correlation coefficient $r=0.969$. The linear range of $[\mathrm{KI}]_{0}$ is $2.72 \times 10^{-3} \mathrm{~mol} / \mathrm{L}-4.08 \times 10^{-3} \mathrm{~mol} / \mathrm{L}$. The range of amplitude $P$ is $1.07 \times 10^{-2}-2.27 \times 10^{-2}$, and it increases with the initial concentration of potassium iodide.

In (1), $T$ represents the period of the sine function. That is to say, it represents the period of the oscillation reaction. The value of $T$ is also dependent on the initial concentration of potassium iodide according to the following equation:

$$
T=-10.4+8.02 \times 10^{3}[\mathrm{KI}]_{0}
$$

with the linear correlation coefficient $r=0.982$. The linear range of $[\mathrm{KI}]_{0}$ is $2.72 \times 10^{-3} \mathrm{~mol} / \mathrm{L}-4.08 \times 10^{-3} \mathrm{~mol} / \mathrm{L}$. The range of period of oscillation $T$ is $11.4-22.3 \mathrm{~s}$, and it increases with the initial concentration of potassium iodide.

3.3. Chlorine Dioxide Initial Concentration. The reaction conditions were fixed at $[\mathrm{KI}]_{0}=3.82 \times 10^{-3} \mathrm{~mol} / \mathrm{L}$, $\left[\mathrm{H}_{2} \mathrm{SO}_{4}\right]_{0}=3.50 \times 10^{-3} \mathrm{~mol} / \mathrm{L}$, and $[\mathrm{MAA}]_{0}=6.29 \times$ $10^{-3} \mathrm{~mol} / \mathrm{L}$ with different $\left[\mathrm{ClO}_{2}\right]_{0}$. Figure 3 gives the absorbance changes with reaction time at $289 \mathrm{~nm}$ for the triiodide ion. As shown in Figure 3, the oscillation phenomenon does not occur as long as the reactants are mixed. There is a preoscillatory or induction period. The oscillation phenomenon is obvious in the range of $8.43 \times 10^{-4} \mathrm{~mol} / \mathrm{L} \leqslant$ $\left[\mathrm{ClO}_{2}\right]_{0} \leqslant 9.51 \times 10^{-4} \mathrm{~mol} / \mathrm{L}$. The amplitude and the number of oscillations are associated with the initial concentration of chlorine dioxide. As the initial concentration of chlorine dioxide increases, the amplitude decreases, while the number of oscillations increases.

We can also differentiate the curves in Figure 3, and get the new curves of triiodide ion reaction rate change with reaction time. Also, we got (1) of triiodide ion reaction rate change with reaction time and the initial concentration of chlorine dioxide in the oscillation stage.

In (1), the value of $P$ is dependent on the initial concentration of chlorine dioxide according to the following equation:

$$
P=0.103-96.9\left[\mathrm{ClO}_{2}\right]_{0}
$$

with the linear correlation coefficient $r=0.972$. The linear range of $\left[\mathrm{ClO}_{2}\right]_{0}$ is $8.43 \times 10^{-4} \mathrm{~mol} / \mathrm{L}-9.51 \times 10^{-4} \mathrm{~mol} / \mathrm{L}$. The range of amplitude $P$ is $2.13 \times 10^{-2}-1.08 \times 10^{-2}$ and decreases with the initial concentration of chlorine dioxide. 


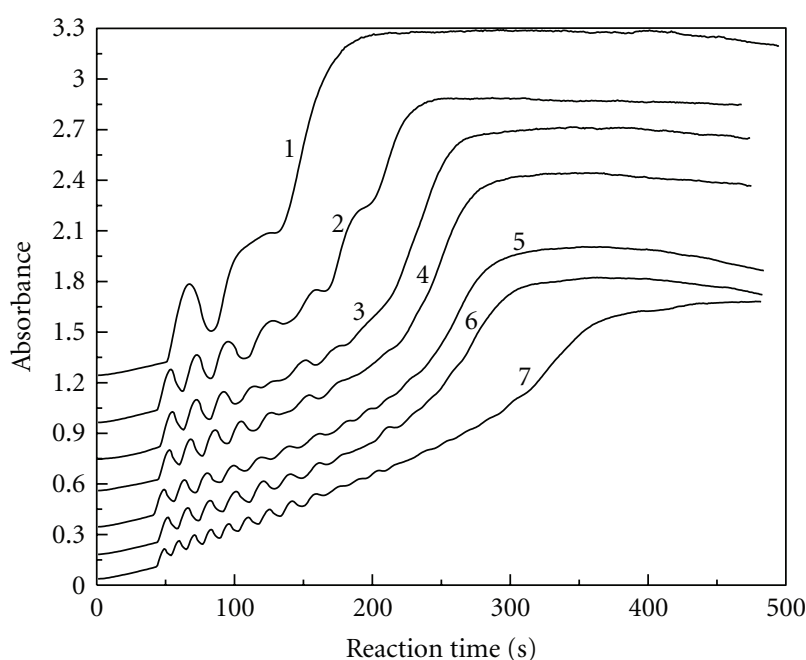

FIgURE 3: The absorbance versus reaction time at $289 \mathrm{~nm}$ for the triiodide ion: $[\mathrm{MAA}]_{0}=6.29 \times 10^{-3} \mathrm{~mol} / \mathrm{L},\left[\mathrm{H}_{2} \mathrm{SO}_{4}\right]_{0}=$ $3.50 \times 10^{-3} \mathrm{~mol} / \mathrm{L},[\mathrm{KI}]_{0}=3.82 \times 10^{-3} \mathrm{~mol} / \mathrm{L},\left[\mathrm{ClO}_{2}\right]_{0}=8.43 \times$ $10^{-4} \mathrm{~mol} / \mathrm{L}$ (curve 1 ), $8.52 \times 10^{-4} \mathrm{~mol} / \mathrm{L}$ (curve 2 ), $8.76 \times 10^{-4} \mathrm{~mol} / \mathrm{L}$ (curve 3), $9.02 \times 10^{-4} \mathrm{~mol} / \mathrm{L}$ (curve 4 ), $9.11 \times 10^{-4} \mathrm{~mol} / \mathrm{L}$ (curve 5), $9.26 \times 10^{-4} \mathrm{~mol} / \mathrm{L}$ (curve 6), $9.51 \times 10^{-4} \mathrm{~mol} / \mathrm{L}$ (curve 7 ).

In (1), the value of $T$ is also dependent on the initial concentration of chlorine dioxide according to the following equation:

$$
T=61.2-4.88 \times 10^{4}\left[\mathrm{ClO}_{2}\right]_{0}
$$

with the linear correlation coefficient $r=0.980$. The linear range of $\left[\mathrm{ClO}_{2}\right]_{0}$ is $8.43 \times 10^{-4} \mathrm{~mol} / \mathrm{L}-9.51 \times 10^{-4} \mathrm{~mol} / \mathrm{L}$. The range of period of oscillation $T$ is $20.1-14.8 \mathrm{~s}$ and decreases with the initial concentration of chlorine dioxide.

3.4. MAA Initial Concentration. For the reaction of $\mathrm{ClO}_{2}-\mathrm{KI}-$ MAA in $\mathrm{H}_{2} \mathrm{SO}_{4}$ medium, the reaction condition was fixed at $[\mathrm{KI}]_{0}=3.82 \times 10^{-3} \mathrm{~mol} / \mathrm{L},\left[\mathrm{ClO}_{2}\right]_{0}=3.40 \times 10^{-4} \mathrm{~mol} / \mathrm{L}$, and $\left[\mathrm{H}_{2} \mathrm{SO}_{4}\right]_{0}=4.21 \times 10^{-3} \mathrm{~mol} / \mathrm{L}$ with different $[\mathrm{MAA}]_{0}$. Figure 4 gives the absorbance changing with the reaction time at $289 \mathrm{~nm}$ for the triiodide ion. As shown in Figure 4, the oscillation phenomenon does not occur as long as the reactants are mixed. There is a preoscillatory or induction period. The oscillation phenomenon is obvious in the range of $5.66 \times 10^{-3} \mathrm{~mol} / \mathrm{L} \leqslant[\mathrm{MAA}]_{0} \leqslant 7.24 \times 10^{-3} \mathrm{~mol} / \mathrm{L}$. The amplitude and the number of oscillations are associated with the initial concentration of MAA. As the initial concentration of MAA increases, the amplitude also increases, but the number of oscillations decreases.

We can also differentiate the curves in Figure 4, and get the new curves of triiodide ion reaction rate change with reaction time. Also, we got (1) of triiodide ion reaction rate change with reaction time and the initial concentration of MAA in the oscillation stage.

In (1), the value of $P$ is dependent on the initial concentration of MAA according to the following equation:

$$
P=-7.42 \times 10^{-2}+15.6[\mathrm{MAA}]_{0}
$$

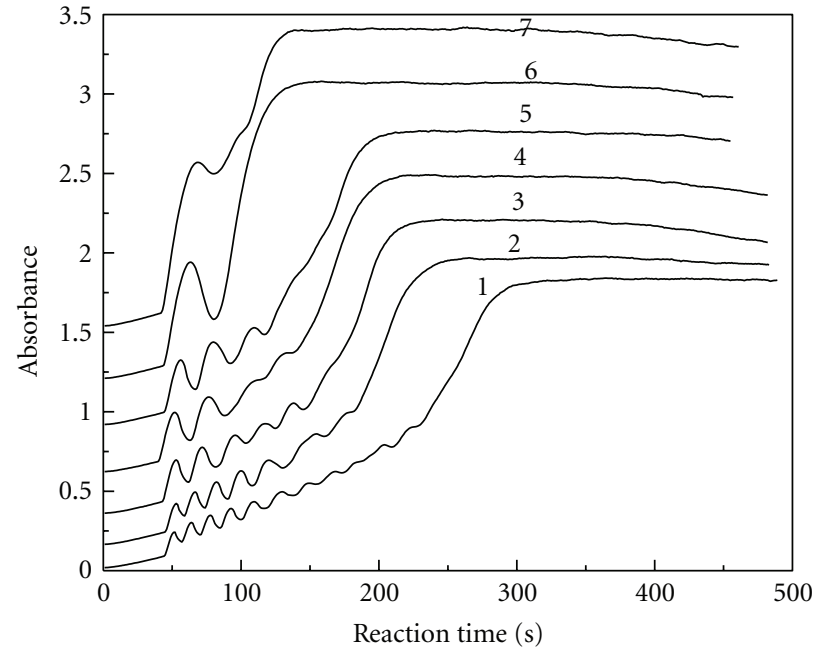

Figure 4: The absorbance versus reaction time at $289 \mathrm{~nm}$ for the triiodide ion: $\left[\mathrm{ClO}_{2}\right]_{0}=3.40 \times 10^{-4} \mathrm{~mol} / \mathrm{L},\left[\mathrm{H}_{2} \mathrm{SO}_{4}\right]_{0}=$ $4.21 \times 10^{-3} \mathrm{~mol} / \mathrm{L},[\mathrm{KI}]_{0}=3.82 \times 10^{-3} \mathrm{~mol} / \mathrm{L},[\mathrm{MAA}]_{0}=5.66$ $\times 10^{-3} \mathrm{~mol} / \mathrm{L}$ (curve 1), $5.98 \times 10^{-3} \mathrm{~mol} / \mathrm{L}$ (curve 2), $6.29 \times$ $10^{-3} \mathrm{~mol} / \mathrm{L}$ (curve 3), $6.61 \times 10^{-3} \mathrm{~mol} / \mathrm{L}$ (curve 4$), 6.92 \times$ $10^{-3} \mathrm{~mol} / \mathrm{L}$ (curve 5 ), $7.08 \times 10^{-3} \mathrm{~mol} / \mathrm{L}$ (curve 6 ), $7.24 \times$ $10^{-3} \mathrm{~mol} / \mathrm{L}$ (curve 7 ).

with the linear correlation coefficient $r=0.975$. The linear range of $[\mathrm{MAA}]_{0}$ is $5.66 \times 10^{-3} \mathrm{~mol} / \mathrm{L}-7.08 \times 10^{-3} \mathrm{~mol} / \mathrm{L}$. The range of amplitude $P$ is $1.41 \times 10^{-2}-3.62 \times 10^{-2}$ and increases with the initial concentration of MAA.

In (1), the value of $T$ is also dependent on the initial concentration of MAA according to the following equation:

$$
T=32.6+8.41 \times 10^{3}[\mathrm{MAA}]_{0}
$$

with the linear correlation coefficient $r=0.998$. The linear range of $[\mathrm{MAA}]_{0}$ is $5.66 \times 10^{-3} \mathrm{~mol} / \mathrm{L}-7.08 \times 10^{-3} \mathrm{~mol} / \mathrm{L}$. The range of period of oscillation $T$ is $15.0-26.9 \mathrm{~s}$ and increases with the initial concentration of MAA.

3.5. Sulfuric Acid Initial Concentration. The reaction conditions were fixed at $[\mathrm{MAA}]_{0}=6.29 \times 10^{-3} \mathrm{~mol} / \mathrm{L},\left[\mathrm{ClO}_{2}\right]_{0}$ $=3.86 \times 10^{-4} \mathrm{~mol} / \mathrm{L}$, and $[\mathrm{KI}]_{0}=3.82 \times 10^{-3} \mathrm{~mol} / \mathrm{L}$ while the initial sulfuric acid concentration was varied. Figure 5 gives the absorbance change with reaction time at $289 \mathrm{~nm}$ for the triiodide ion. As shown in Figure 5, the oscillation phenomenon does not occur as long as the reactants are mixed. There is a preoscillatory or induction period. The oscillation phenomenon is obvious in the whole range of $\left[\mathrm{H}_{2} \mathrm{SO}_{4}\right]_{0}=3.50 \times 10^{-3} \mathrm{~mol} / \mathrm{L}-7.71 \times 10^{-3} \mathrm{~mol} / \mathrm{L}$. The amplitude is large at the beginning stage then decreases with reaction time. Finally, the oscillation ceases suddenly. The number of oscillations increases with the increase of the initial concentration of sulfuric acid.

Differentiation of the curve in Figure 5 yields new curves and we can get (1) for the reaction rate changes with reaction time and the initial concentration of $\mathrm{H}_{2} \mathrm{SO}_{4}$ in the oscillation stage. 


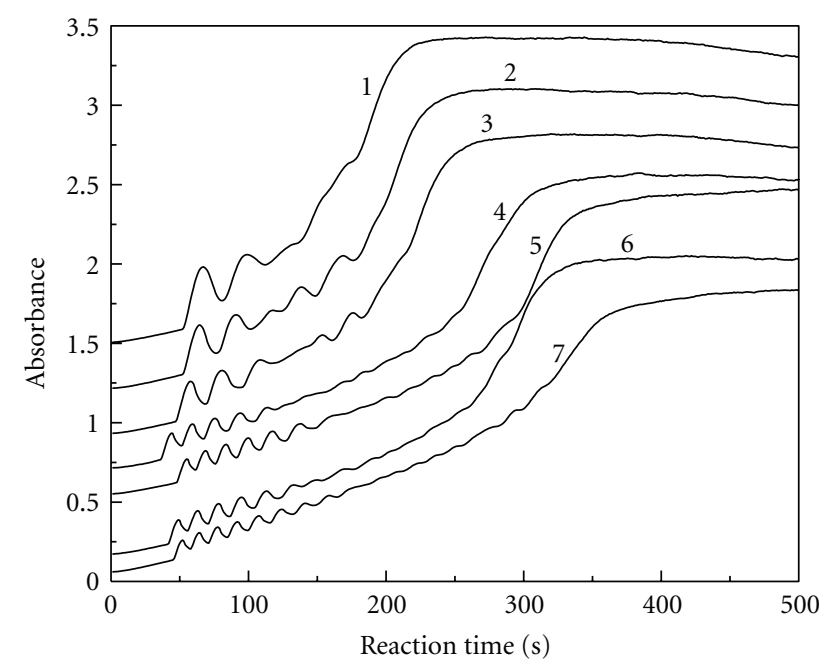

Figure 5: The absorbance versus reaction time at $289 \mathrm{~nm}$ for the triiodide ion: $[\mathrm{MAA}]_{0}=6.29 \times 10^{-3} \mathrm{~mol} / \mathrm{L},[\mathrm{KI}]_{0}=3.82 \times 10^{-3} \mathrm{~mol} / \mathrm{L}$, $\left[\mathrm{ClO}_{2}\right]_{0}=3.86 \times 10^{-4} \mathrm{~mol} / \mathrm{L},\left[\mathrm{H}_{2} \mathrm{SO}_{4}\right]_{0}=3.50 \times 10^{-3} \mathrm{~mol} / \mathrm{L}$ (curve 1 ), $4.21 \times 10^{-3} \mathrm{~mol} / \mathrm{L}$ (curve 2), $4.91 \times 10^{-3} \mathrm{~mol} / \mathrm{L}$ (curve 3 ), $5.61 \times 10^{-3} \mathrm{~mol} / \mathrm{L}$ (curve 4$), 6.31 \times 10^{-3} \mathrm{~mol} / \mathrm{L}$ (curve 5), $7.01 \times$ $10^{-3} \mathrm{~mol} / \mathrm{L}$ (curve 6), $7.71 \times 10^{-3} \mathrm{~mol} / \mathrm{L}$ (curve 7 ).

In (1), the value of $P$ is dependent on the initial concentration of $\mathrm{H}_{2} \mathrm{SO}_{4}$ according to the following equation:

$$
P=3.16 \times 10^{-2}-2.76\left[\mathrm{H}_{2} \mathrm{SO}_{4}\right]_{0}
$$

with the linear correlation coefficient $r=0.975$. The linear range of $\left[\mathrm{H}_{2} \mathrm{SO}_{4}\right]_{0}$ is $3.50 \times 10^{-3} \mathrm{~mol} / \mathrm{L}-7.71 \times 10^{-3} \mathrm{~mol} / \mathrm{L}$. The range of amplitude $P$ is $2.19 \times 10^{-2}-1.03 \times 10^{-2}$, and it decreases with the initial concentration of $\mathrm{H}_{2} \mathrm{SO}_{4}$.

In (1), the value of $T$ is also dependent on the initial concentration of $\mathrm{H}_{2} \mathrm{SO}_{4}$ according to the following equation:

$$
T=39.0-3.40 \times 10^{3}\left[\mathrm{H}_{2} \mathrm{SO}_{4}\right]_{0}
$$

with the linear correlation coefficient $r=0.963$. The linear range of $\left[\mathrm{H}_{2} \mathrm{SO}_{4}\right]_{0}$ is $3.50 \times 10^{-3} \mathrm{~mol} / \mathrm{L}-7.71 \times 10^{-3} \mathrm{~mol} / \mathrm{L}$. The range of period of oscillation $T$ is $27.1-12.8 \mathrm{~s}$, and it decreases with the initial concentration of $\mathrm{H}_{2} \mathrm{SO}_{4}$.

3.6. The Influence of Dilution. In order to investigate the influence of the reactant concentrations on the oscillation, experiments were carried out by fixing $\left[\mathrm{H}_{2} \mathrm{SO}_{4}\right]_{0}=3.50 \times$ $10^{-3} \mathrm{~mol} / \mathrm{L}$ and $[\mathrm{MAA}]_{0}=6.29 \times 10^{-3} \mathrm{~mol} / \mathrm{L}$ keeping the molar ratio of $\left[\mathrm{ClO}_{2}\right]_{0} /[\mathrm{KI}]_{0}=0.115$, and changing the initial concentrations of chlorine dioxide and potassium iodide at the same time. Figure 6 gives the absorbance change with reaction time at $289 \mathrm{~nm}$ for the triiodide ion at different initial concentrations of chlorine dioxide and potassium iodide. As shown in Figure 6, the oscillation phenomenon occurs in the whole range of $\left[\mathrm{ClO}_{2}\right]_{0}=4.01 \times 10^{-4} \mathrm{~mol} / \mathrm{L}-$ $5.29 \times 10^{-4} \mathrm{~mol} / \mathrm{L}$ and $[\mathrm{KI}]_{0}=3.48 \times 10^{-3} \mathrm{~mol} / \mathrm{L}-4.59 \times$ $10^{-3} \mathrm{~mol} / \mathrm{L}$. There is a preoscillatory or induction period; when the initial concentrations of chlorine dioxide and potassium iodide are higher, the oscillation phenomenon is more obvious and regular. The amplitude decreases and the

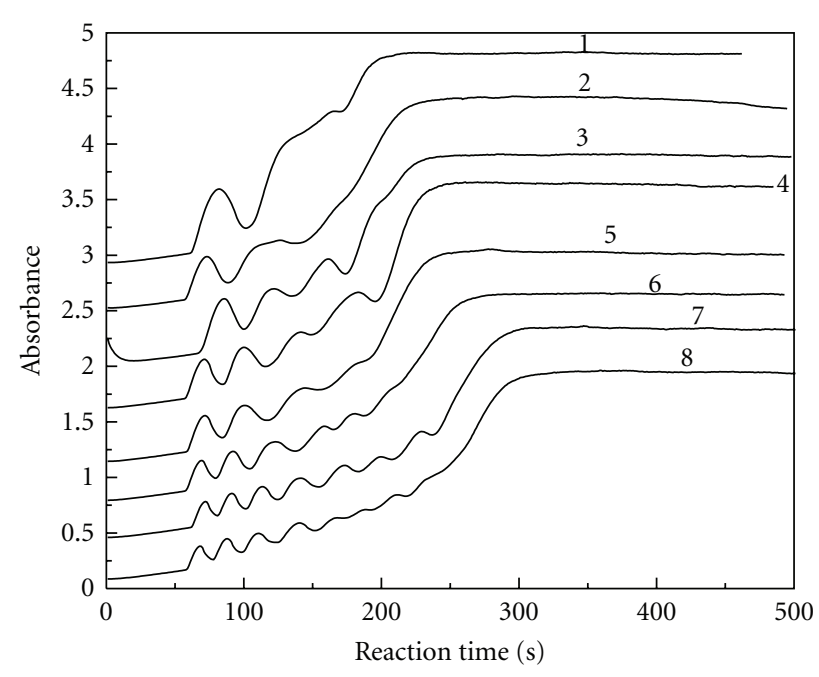

FIGURE 6: The absorbance versus reaction time at $289 \mathrm{~nm}$ for the triiodide ion: $\left[\mathrm{ClO}_{2}\right]_{0} /[\mathrm{KI}]_{0}=0.115,[\mathrm{MAA}]_{0}=6.29 \times 10^{-3} \mathrm{~mol} / \mathrm{L}$, $\left[\mathrm{H}_{2} \mathrm{SO}_{4}\right]_{0}=3.50 \times 10^{-3} \mathrm{~mol} / \mathrm{L},\left[\mathrm{ClO}_{2}\right]_{0}=4.01 \times 10^{-4} \mathrm{~mol} / \mathrm{L},[\mathrm{KI}]_{0}$ $=3.48 \times 10^{-3} \mathrm{~mol} / \mathrm{L}($ curve 1$) ;\left[\mathrm{ClO}_{2}\right]_{0}=4.21 \times 10^{-4} \mathrm{~mol} / \mathrm{L},[\mathrm{KI}]_{0}$ $=3.65 \times 10^{-3} \mathrm{~mol} / \mathrm{L}($ curve 2$) ;\left[\mathrm{ClO}_{2}\right]_{0}=4.40 \times 10^{-4} \mathrm{~mol} / \mathrm{L},[\mathrm{KI}]_{0}=$ $3.82 \times 10^{-3} \mathrm{~mol} / \mathrm{L}($ curve 3$) ;\left[\mathrm{ClO}_{2}\right]_{0}=4.60 \times 10^{-4} \mathrm{~mol} / \mathrm{L},[\mathrm{KI}]_{0}=$ $3.99 \times 10^{-3} \mathrm{~mol} / \mathrm{L}($ curve 4$) ;\left[\mathrm{ClO}_{2}\right]_{0}=4.70 \times 10^{-4} \mathrm{~mol} / \mathrm{L},[\mathrm{KI}]_{0}=$ $4.08 \times 10^{-3} \mathrm{~mol} / \mathrm{L}($ curve 5$) ;\left[\mathrm{ClO}_{2}\right]_{0}=4.89 \times 10^{-4} \mathrm{~mol} / \mathrm{L},[\mathrm{KI}]_{0}=$ $4.25 \times 10^{-3} \mathrm{~mol} / \mathrm{L}$ (curve 6); $\left[\mathrm{ClO}_{2}\right]_{0}=5.09 \times 10^{-4} \mathrm{~mol} / \mathrm{L},[\mathrm{KI}]_{0}=$ $4.42 \times 10^{-3} \mathrm{~mol} / \mathrm{L}($ curve 7$) ;\left[\mathrm{ClO}_{2}\right]_{0}=5.29 \times 10^{-4} \mathrm{~mol} / \mathrm{L},[\mathrm{KI}]_{0}=$ $4.59 \times 10^{-3} \mathrm{~mol} / \mathrm{L}$ (curve 8 ).

number of oscillations increases along with the increase of the initial concentration of chlorine dioxide and potassium iodide.

3.7. $p H$ Value. The reaction conditions were fixed at $[\mathrm{MAA}]_{0}$ $=6.29 \times 10^{-3} \mathrm{~mol} / \mathrm{L},\left[\mathrm{ClO}_{2}\right]_{0}=5.96 \times 10^{-4} \mathrm{~mol} / \mathrm{L}$, and $[\mathrm{KI}]_{0}$ $=3.82 \times 10^{-3} \mathrm{~mol} / \mathrm{L}$ while the $\mathrm{pH}$ value was varied. Figure 7 gives the absorbance change with reaction time at $289 \mathrm{~nm}$ for the triiodide ion. As shown in Figure 7, the oscillation phenomenon does not occur as long as the reactants are mixed. There is a preoscillatory or induction period. The oscillation phenomenon is obvious in the whole range of $\mathrm{pH}=2.2-4.0$. At $\mathrm{pH}$ values above 4.0, it is difficult to observe the oscillation (see curve 6). The amplitude is large at the beginning stage then decreases with reaction time. Finally, the oscillation ceases suddenly. The amplitude and the number of oscillations are associated with the $\mathrm{pH}$ value. As the $\mathrm{pH}$ value increases, the amplitude increases, but the number of oscillations decreases.

3.8. The Influence of Temperature on the Oscillation. Figure 8 gives the absorbance changes with reaction time at $289 \mathrm{~nm}$ for the triiodide ion. The reaction conditions were fixed at $\left[\mathrm{ClO}_{2}\right]_{0}=1.92 \times 10^{-3} \mathrm{~mol} / \mathrm{L},[\mathrm{MAA}]_{0}=3.93 \times 10^{-3} \mathrm{~mol} / \mathrm{L}$, $\left[\mathrm{H}_{2} \mathrm{SO}_{4}\right]_{0}=4.14 \times 10^{-3} \mathrm{~mol} / \mathrm{L}$, and $[\mathrm{KI}]_{0}=3.22 \times$ $10^{-3} \mathrm{~mol} / \mathrm{L}$. Five oscillation curves were obtained in the temperature range of $25^{\circ} \mathrm{C}$ to $55^{\circ} \mathrm{C}$. As shown in Figure 8 , both the induction period and the oscillation period decrease with the increasing of reaction temperature. The experiments 


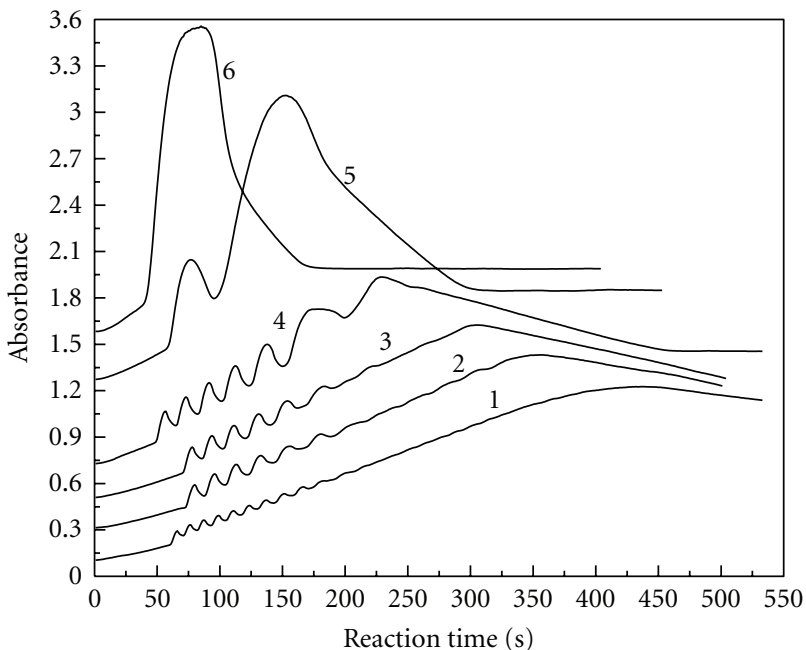

Figure 7: The absorbance versus reaction time at $289 \mathrm{~nm}$ for the triiodide ion: $[\mathrm{MAA}]_{0}=6.29 \times 10^{-3} \mathrm{~mol} / \mathrm{L},[\mathrm{KI}]_{0}=3.82 \times$ $10^{-3} \mathrm{~mol} / \mathrm{L},\left[\mathrm{ClO}_{2}\right]_{0}=5.96 \times 10^{-4} \mathrm{~mol} / \mathrm{L}, \mathrm{pH}=2.2($ curve 1$), 2.6$ (curve 2), 3.0 (curve 3), 3.6 (curve 4), 4.0 (curve 5), 4.6 (curve 6).

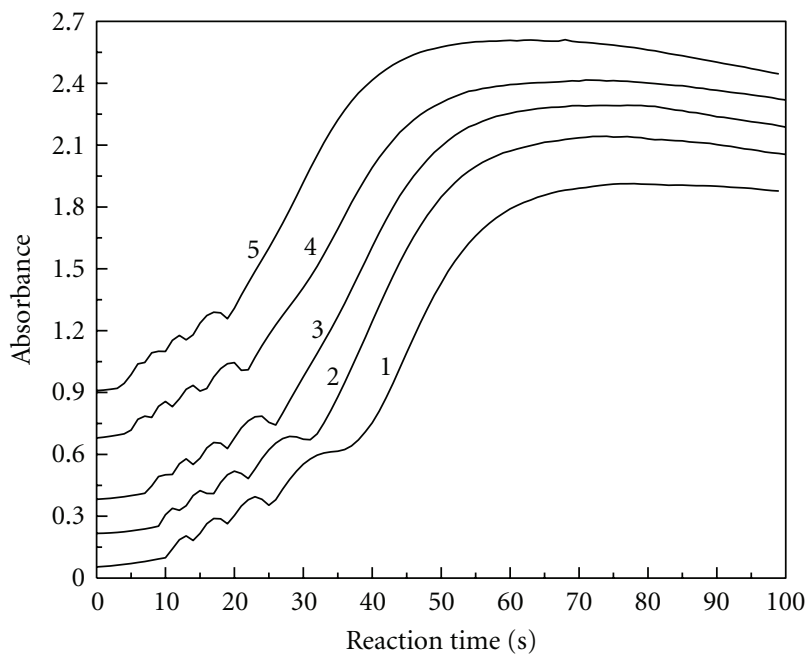

Figure 8: The absorbance versus reaction time at $289 \mathrm{~nm}$ for the triiodide ion: $\left[\mathrm{ClO}_{2}\right]_{0}=1.92 \times 10^{-3} \mathrm{~mol} / \mathrm{L},[\mathrm{MAA}]_{0}=3.93$ $\times 10^{-3} \mathrm{~mol} / \mathrm{L},\left[\mathrm{H}_{2} \mathrm{SO}_{4}\right]_{0}=4.14 \times 10^{-3} \mathrm{~mol} / \mathrm{L},[\mathrm{KI}]_{0}=3.22 \times$ $10^{-3} \mathrm{~mol} / \mathrm{L}, 25^{\circ} \mathrm{C}$ (curve 1 ), $30^{\circ} \mathrm{C}$ (curve 2 ), $35^{\circ} \mathrm{C}$ (curve 3 ), $45^{\circ} \mathrm{C}$ (curve 4 ), $55^{\circ} \mathrm{C}$ (curve 5).

show that oscillation reaction can be accelerated by increasing reaction temperature, but oscillation life is shortened.

According to the Arrhenius equation

$$
k=A \cdot e^{-E a / R T},
$$

taking the logarithm of (10)

$$
\ln k=\ln A-\left(\frac{E a}{R T}\right)
$$

$\ln k \sim(1 / T)$ should be linear relationship. The slope is $-E a / R$. Thus, the activation energy $E a$ can be calculated.
TABLE 1: The induction time $(t u)$ and the oscillation period $(t z)$ at various reaction temperatures.

\begin{tabular}{lccccc}
\hline Reaction temperature $(\mathrm{K})$ & 298.0 & 303.0 & 308.0 & 318.0 & 328.0 \\
\hline$t u(\mathrm{~s})$ & 10.0 & 9.0 & 7.0 & 5.0 & 4.0 \\
$t z(\mathrm{~s})$ & 6.0 & 5.0 & 5.0 & 4.0 & 3.0 \\
\hline
\end{tabular}

The aim of the experiment is to study the apparent activation energy $(E u)$ in terms of the induction period and the apparent activation energy $(E z)$ in terms of the oscillation period in the oscillation reaction. The induction time $(t u)$ and the oscillation period $(t z)$ can be obtained from Figure 8 . Therefore, (11) can be written as

$$
\begin{aligned}
& \ln \left(\frac{1}{t u}\right)=\ln A-\left(\frac{E u}{R T}\right), \\
& \ln \left(\frac{1}{t z}\right)=\ln A-\left(\frac{E z}{R T}\right) .
\end{aligned}
$$

$\ln (1 / t u) \sim 1 / T$ and $\ln (1 / t z) \sim 1 / T$ should be linear relationships, respectively. Thus, the apparent activation energies $E u$ and $E z$ can be calculated, respectively.

Table 1 gives the induction time $(t u)$ and the oscillation period $(t z)$ at various reaction temperatures. Figure 9 shows the linear fitting of $\ln (1 / t u)$ versus $1 / T$. Figure 10 shows the linear fitting of $\ln (1 / t z)$ versus $1 / T$. Therefore, (12) can be written as

$$
\begin{aligned}
& \ln \left(\frac{1}{t u}\right)=8.185-3129\left(\frac{1}{T}\right), \\
& \ln \left(\frac{1}{t z}\right)=5.335-2123\left(\frac{1}{T}\right) .
\end{aligned}
$$

The linear correlation coefficient of (13) is 0.994. By using the slope of (13), we can obtain the apparent activation energy $(E u)$ in terms of the induction period is $26.02 \mathrm{KJ} / \mathrm{mol}$. The linear correlation coefficient of (14) is 0.982 . By using the slope of (14), we can get that the apparent activation energy $(E z)$ in terms of the oscillation period is $17.65 \mathrm{KJ} / \mathrm{mol}$. The apparent activation energy of the oscillation reaction is relatively small.

3.9. Online FTIR Analysis during the Oscillation Reaction. Figure 11 gives the $3 \mathrm{D}$ online infrared spectrum during the oscillation reaction. In Figure 11, the strong absorption near $3307 \mathrm{~cm}^{-1}$ is assigned to the $\mathrm{O}-\mathrm{H}$ stretching of water. The strong absorption near $1652 \mathrm{~cm}^{-1}$ is assigned to the $\mathrm{H}-\mathrm{O}-\mathrm{H}$ bending of water.

Two intermediates were detected automatically during the online FTIR analysis, and their FTIR spectra were obtained. In the FTIR spectrum of intermediate 1 (Figure 12), the absorption near $1747 \mathrm{~cm}^{-1}$ (peak 1) is assigned to the $\mathrm{C}=\mathrm{O}$ stretching. The absorption near $1652 \mathrm{~cm}^{-1}$ (peak 2) and $1629 \mathrm{~cm}^{-1}$ (peak 3) is assigned to the $\mathrm{C}=\mathrm{O}$ stretching of an enol isomer of keto-enol tautomerism. The absorptions near 1544, 1525, and $1513 \mathrm{~cm}^{-1}$ (peak 46) are assigned to the $\mathrm{C}=\mathrm{C}$ stretching of the enol isomer of keto-enol tautomerism. The absorption near $1031 \mathrm{~cm}^{-1}$ (peak 7) is assigned to the $\mathrm{O}-\mathrm{H}$ in-plane deformation in the 


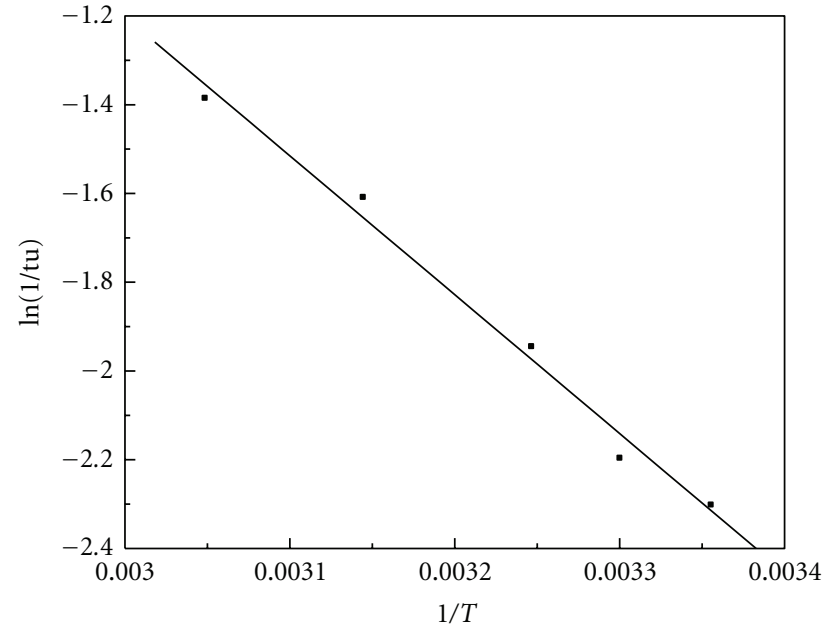

Figure 9: The curve of $\ln (1 / t u)$ versus $1 / T$.

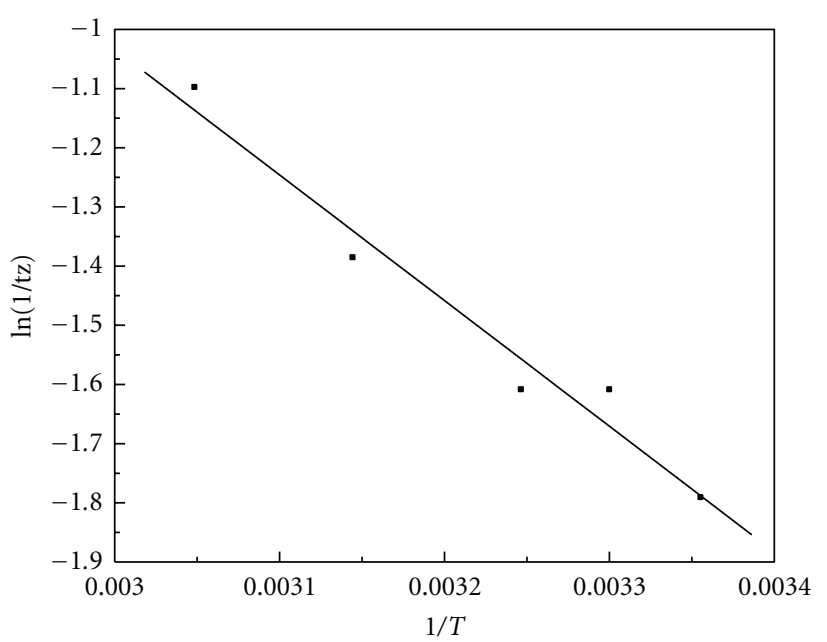

Figure 10: The curve of $\ln (1 / t z)$ versus $1 / T$.

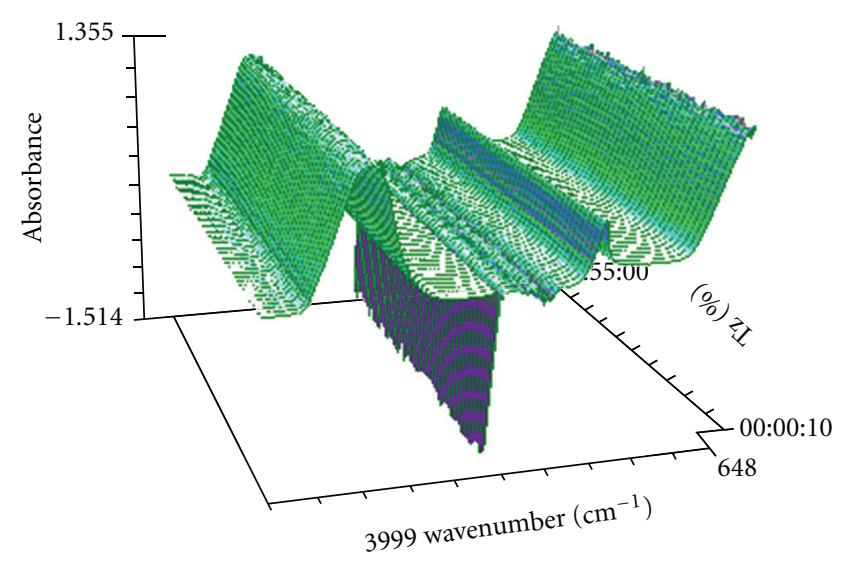

FIGURE 11: The 3D online infrared spectrum during the oscillation reaction.

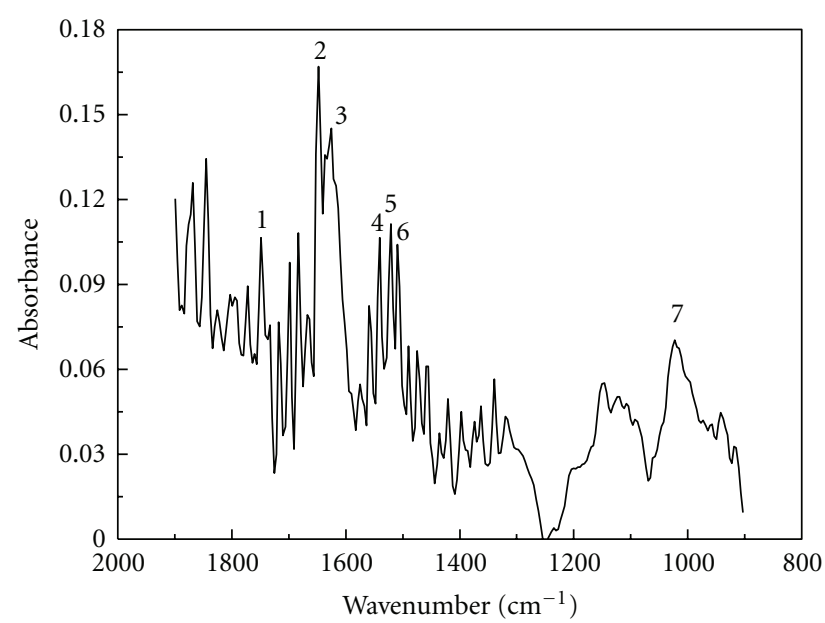

FIGURE 12: FTIR spectrum of intermediate 1.

enol isomer of keto-enol tautomerism. In the FTIR spectrum of intermediate 2 (the figure is omitted), the absorption near $1652 \mathrm{~cm}^{-1}$ is assigned to the $\mathrm{C}=\mathrm{O}$ stretching of the iodinesubstituted keto isomer of keto-enol tautomerism.

Figures 13 and 14 give the relative concentrations $(c)$ of intermediates 1 and 2 versus reaction time. As shown in Figure 13, the relative concentration of intermediate 1 decreases with reaction time. That is to say, the concentration of enol isomer decreases during the oscillation reaction. As shown in Figure 14, the relative concentration of intermediate 2 increases with reaction time. That is to say, the concentration of iodine-substituted keto isomer increases during the oscillation reaction.

According to the literature [12] the behavior of $\mathrm{ClO}_{2}-\mathrm{I}^{-}$MAA chemical oscillatory reaction system can be modeled by a simple scheme consisting of three component reactions. The reactions should be as follows

$$
\begin{aligned}
& \mathrm{ClO}_{2}+\mathrm{I}^{-} \longrightarrow \mathrm{ClO}_{2}{ }^{-}+1 / 2 \mathrm{I}_{2} \\
& \mathrm{ClO}_{2}{ }^{-}+4 \mathrm{I}^{-}+4 \mathrm{H}^{+} \longrightarrow \mathrm{Cl}^{-}+2 \mathrm{I}_{2}+2 \mathrm{H}_{2} \mathrm{O} \\
& \mathrm{CH}_{3} \mathrm{COCH}_{2} \mathrm{COOCH}_{3}+\mathrm{I}_{2} \\
& \quad \longrightarrow \mathrm{CH}_{3} \mathrm{COCHICOOCH}_{3}+\mathrm{I}^{-}+\mathrm{H}^{+}
\end{aligned}
$$

For reaction (17), we proposed a scheme as shown in reactions (R4)-(R6) based upon the concentration changing trends of the two intermediates in Figures 13 and 14 and in consideration literature [25]. In aqueous solutions putting into the base shown in reaction (R5) may be water or halide ions which are sufficiently basic to act as shown in [26]. One possibility is that either reaction (R5) or (R6) can be a ratedetermining step:

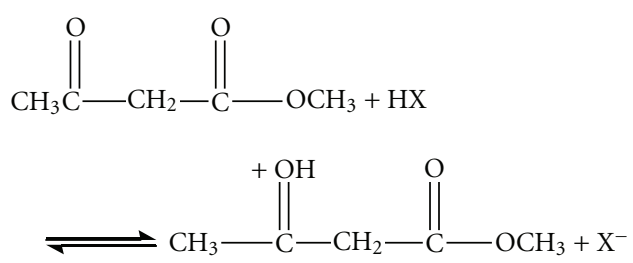




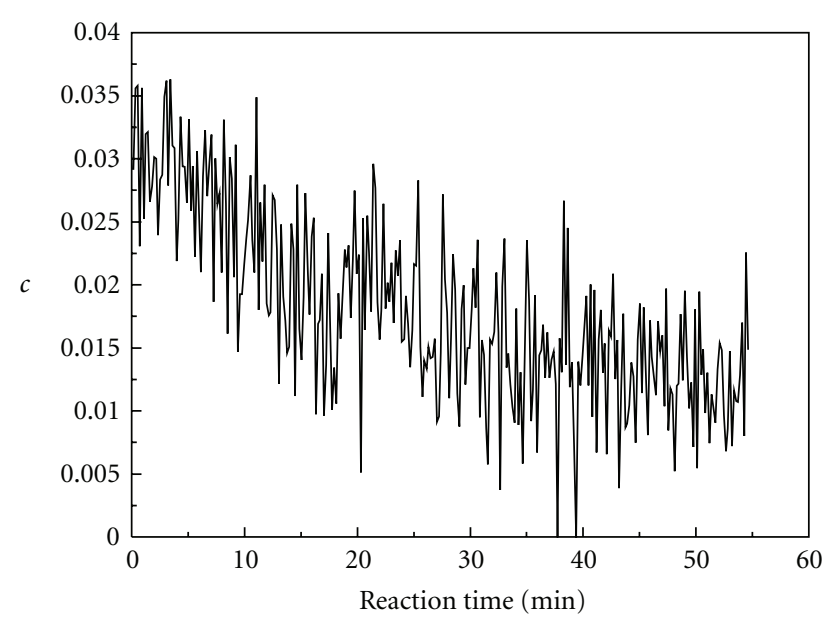

Figure 13: The curve of intermediate 1 relative concentration versus reaction time.

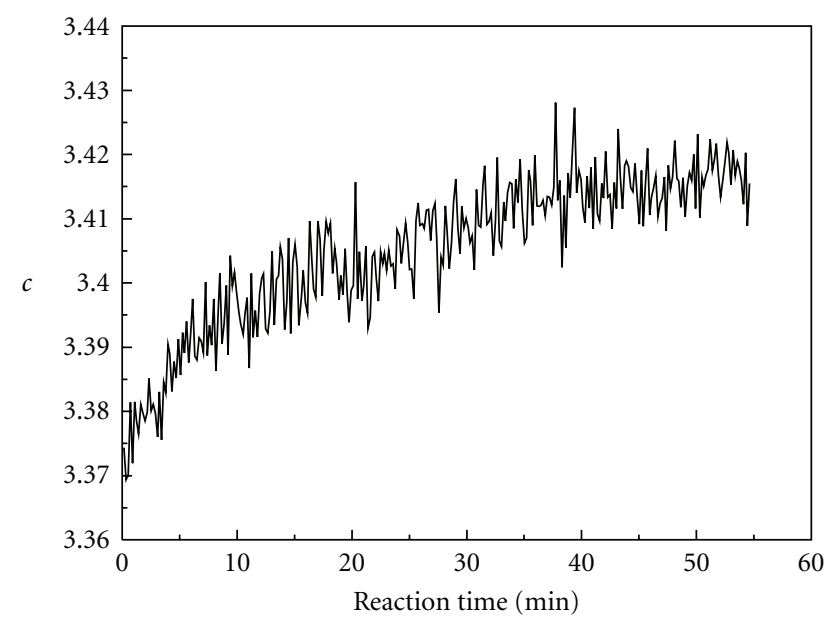

FIGURE 14: The curve of intermediate 2 relative concentration versus reaction time.<smiles>COC(=O)CC(C)=[OH+]</smiles><smiles></smiles>

(Intermediate 1: enol isomer)

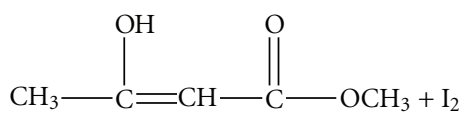

(Intermediate 1: enol isomer)

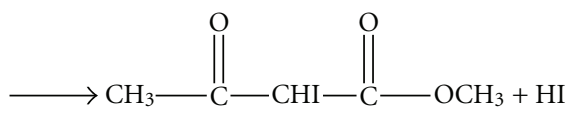

(Intermediate 2: iodine-substituted keto isomer)

\section{Conclusion}

The initial concentrations of methyl acetoacetate, chlorine dioxide, potassium iodide, and sulfuric acid have great influence on the oscillation at $289 \mathrm{~nm}$. There is a preoscillatory or induction period. Equations for the triiodide ion reaction rate changes with reaction time and the initial concentrations in the oscillation stage were obtained. Oscillation reaction can be accelerated by increasing temperature. The apparent activation energy in terms of the induction period or the oscillation period was calculated. The intermediates were detected by the online FTIR analysis. Based upon the experimental data in this work and in the literature, a plausible reaction mechanism was proposed for the oscillation reaction.

\section{Acknowledgments}

The authors would like to thank the financial support from the Shandong Provincial Natural Science Foundation (no. ZR2009BM007) and the Scientific Research Foundation for the Returned Overseas Chinese Scholars, State Education Ministry, China.

\section{References}

[1] R. J. Field, R. M. Noyes, and E. Körös, "Oscillations in chemical systems-II. Thorough analysis of temporal oscillation in the bromate-cerium-malonic acid system," Journal of the American Chemical Society, vol. 94, no. 25, pp. 8649-8664, 1972.

[2] R. J. Field and R. M. Noyes, "Oscillations in chemical systems. IV. Limit cycle behavior in a model of a real chemical reaction," The Journal of Chemical Physics, vol. 60, no. 5, pp. 1877-1884, 1974.

[3] P. De Kepper, "Chlorite-Iodide reaction: a versatile system for the study of nonlinear dynamical behavior," Journal of Physical Chemistry, vol. 94, no. 17, pp. 6525-6536, 1990.

[4] W. C. Bray, "Beitrage zur Kenntnis der Halogensauerstuff verbindungen. Abhandlung III. Zur Kenntnis des Chlordioxyds," Zeitschrift für Physikalische Chemie, vol. 54, pp. 575$581,1906$.

[5] H. Fukutomi and G. Gordon, "Kinetic study of the reaction between chlorine dioxide and potassium iodide in aqueous solution," Journal of the American Chemical Society, vol. 89, no. 6, pp. 1362-1366, 1967.

[6] A. Indelli, "Kinetic study on the reaction of sodium chlorite with potassium iodide," Journal of Physical Chemistry, vol. 68, no. 10, pp. 3027-3031, 1964.

[7] M. Dolnik and I. R. Epstein, "Excitability and bursting in the chlorine dioxide-iodide reaction in a forced open system," The Journal of Chemical Physics, vol. 97, no. 5, pp. 3265-3273, 1992.

[8] M. Dolnik and I. R. Epstein, "A coupled chemical burster: the chlorine dioxide-iodide reaction in two flow reactors," The Journal of Chemical Physics, vol. 98, no. 2, pp. 1149-1155, 1993.

[9] P. De Kepper, I. R. Epstein, K. Kustin, and M. Orbán, “Batch oscillations and spatial wave patterns in chlorite oscillating systems," Journal of Physical Chemistry, vol. 86, no. 2, pp. 170171, 1982. 
[10] P. De Kepper and I. R. Epstein, "A mechanistic study of oscillations and bistability in the Briggs-Rauscher reaction," Journal of the American Chemical Society, vol. 104, no. 1, pp. 49-55, 1982.

[11] I. Lengyel, G. Rábai, and I. R. Epstein, "Batch oscillation in the reaction of chlorine dioxide with iodine and malonic acid," Journal of the American Chemical Society, vol. 112, no. 11, pp. 4606-4607, 1990.

[12] I. Lengyel, G. Rábai, and I. R. Epstein, "Experimental and modeling study of oscillations in the chlorine dioxide-iodinemalonic acid reaction," Journal of the American Chemical Society, vol. 112, no. 25, pp. 9104-9110, 1990.

[13] I. Lengyel, J. Li, K. Kustin, and I. R. Epstein, "Rate constants for reactions between iodine- and chlorine-containing species: a detailed mechanism of the chlorine dioxide/chlorite-iodide reaction," Journal of the American Chemical Society, vol. 118, no. 15, pp. 3708-3719, 1996.

[14] I. Lengyel and I. R. Epstein, "Modeling of turing structures in the chlorite-iodide-malonic acid-starch reaction system," Science, vol. 251, no. 4994, pp. 650-652, 1991.

[15] I. Lengyel, S. Kádár, and I. R. Epstein, "Transient turing structures in a gradient-free closed system," Science, vol. 259, no. 5094, pp. 493-495, 1993.

[16] A. P. Muñuzuri, M. Dolnik, A. M. Zhabotinsky, and I. R. Epstein, "Control of the chlorine dioxide-iodine-malonic acid oscillating reaction by illumination," Journal of the American Chemical Society, vol. 121, no. 35, pp. 8065-8069, 1999.

[17] I. Fábián and G. Gordon, "The kinetics and mechanism of the chlorine dioxide-iodide ion reaction," Inorganic Chemistry, vol. 36, no. 12, pp. 2494-2497, 1997.

[18] D. E. Strier, P. De Kepper, and J. Boissonade, "Turing patterns, spatial bistability, and front interactions in the $\left[\mathrm{ClO}_{2}, \mathrm{I}_{2}, \mathrm{I}^{-}\right.$, $\mathrm{CH}_{2}(\mathrm{COOH})_{2}$ ] reaction," Journal of Physical Chemistry A, vol. 109, no. 7, pp. 1357-1363, 2005.

[19] I. Szalai and P. De Kepper, "Turing patterns, spatial bistability, and front instabilities in a reaction-diffusion system," Journal of Physical Chemistry A, vol. 108, no. 25, pp. 5315-5321, 2004.

[20] S. S. Riaz and D. S. Ray, "Spiral pattern in chlorite-iodidemalonic acid reaction: a theoretical and numerical study," Journal of Chemical Physics, vol. 123, no. 17, Article ID 174506, pp. 1-5, 2005.

[21] D. A. Long, L. Chodroff, T. M. O’Neal, and S. Hemkin, "A true chemical clock: serially coupled chlorite-iodide oscillators," Chemical Physics Letters, vol. 447, no. 4-6, pp. 340-344, 2007.

[22] L. Shi, W. Li, and F. Wang, "Experimental study of a closed system in the chlorine dioxide-iodine-malonic acid-sulfuric acid oscillation reaction by UV-vis spectrophotometric method," Journal of Solution Chemistry, vol. 38, no. 5, pp. 571-588, 2009.

[23] C. Yan, L. Shi, and F. Guo, "Experimental study of a closed system in the sodium chlorite-iodine-ethyl acetoacetate oscillation reaction by UV-Vis and online FTIR spectrophotometric method," Research on Chemical Intermediates, vol. 37, no. 8, pp. 929-947, 2011.

[24] N. Li, L. Shi, X. Wang, F. Guo, and C. Yan, "Experimental study of closed system in the chlorine dioxide-iodide-sulfuric acid reaction by UV-vis spectrophotometric method," International Journal of Analytical Chemistry, vol. 2011, Article ID 130102, 7 pages, 2011.

[25] D. P. Wyman, P. R. Kaufman, and W. R. Freeman, "The chlorination of active hydrogen compounds with sulfuryl chloride. II. Esters, nitriles, nitro compounds, and aldehydes," Journal of Organic Chemistry, vol. 29, no. 9, pp. 2706-2710, 1964.
[26] R. F. W. Cieciuch and F. H. Westheimer, "Halide catalysis in the bromination of deoxybenzoin," Journal of the American Chemical Society, vol. 85, no. 17, pp. 2591-2595, 1963. 


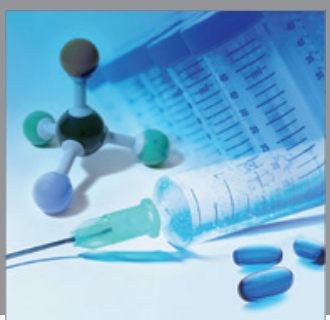

International Journal of

Medicinal Chemistry

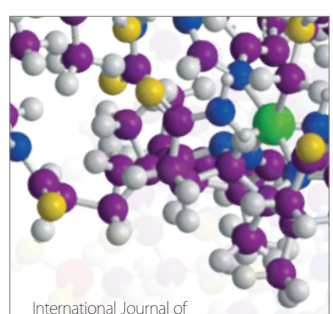

Carbohydrate Chemistry

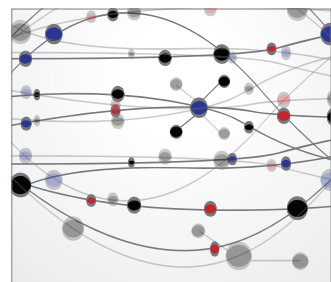

The Scientific World Journal
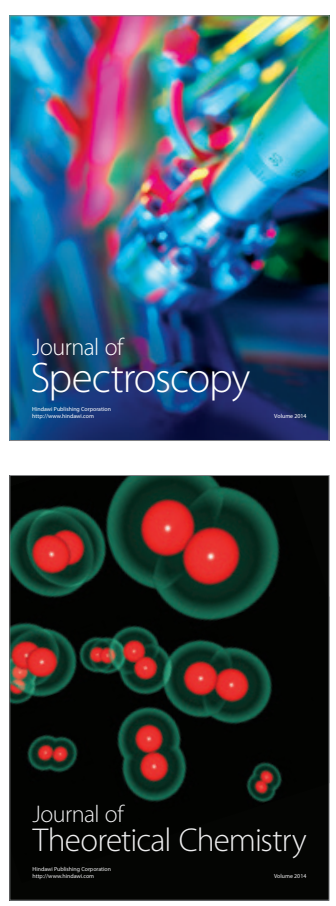
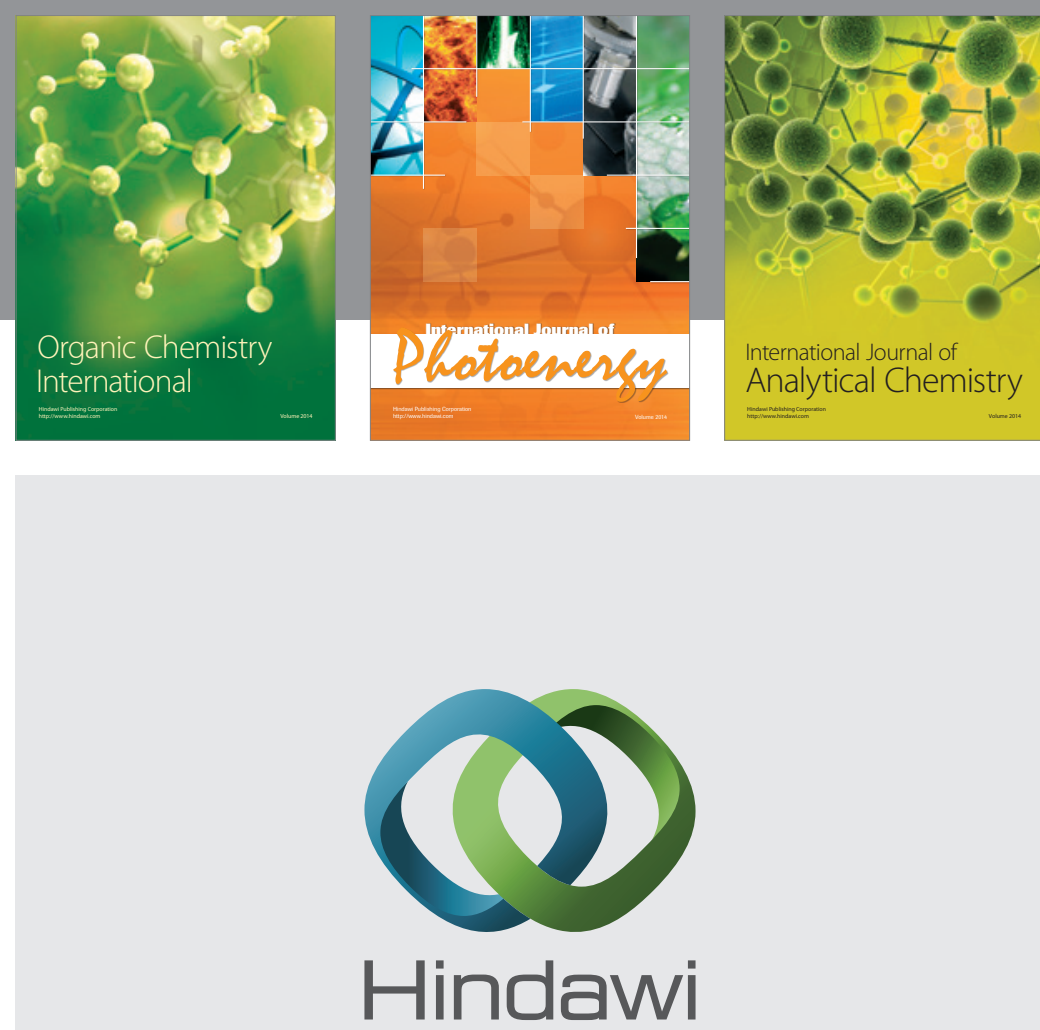

Submit your manuscripts at

http://www.hindawi.com
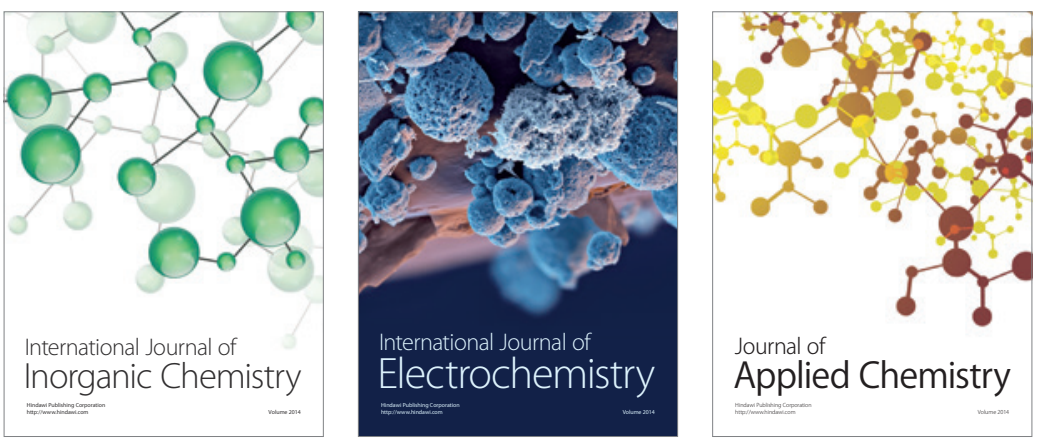

Journal of

Applied Chemistry
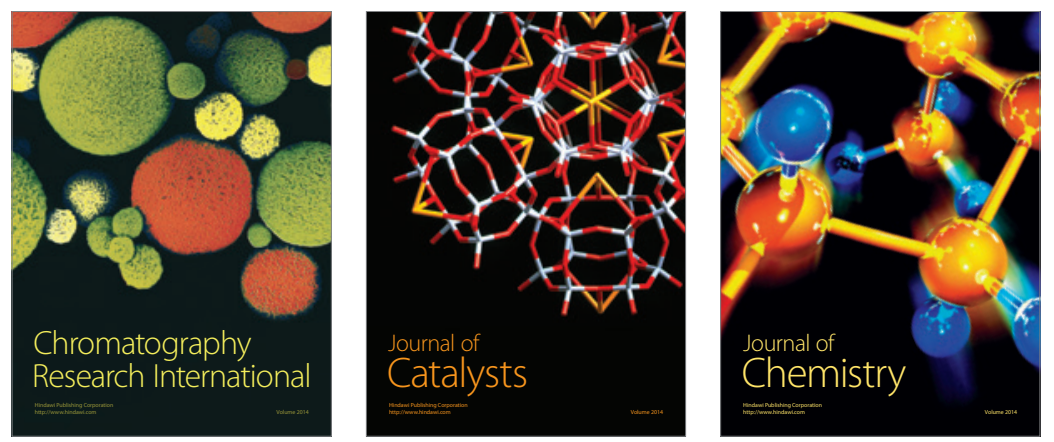
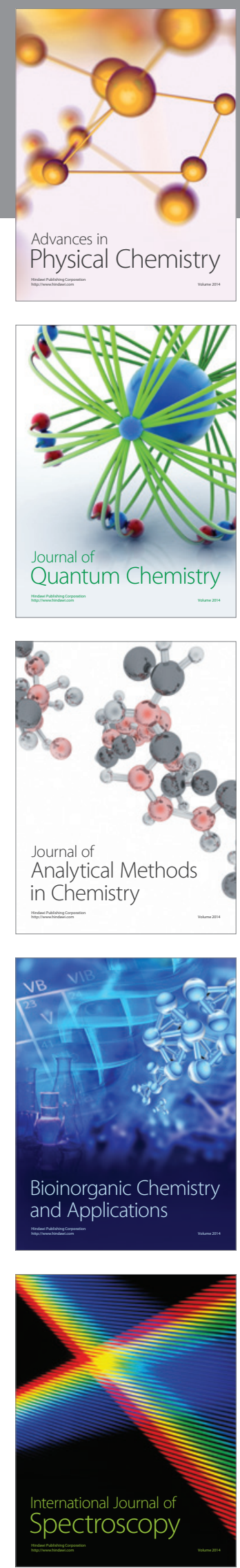